\title{
BIAYA TRANSAKSI DAN BENEFIT COST PADA INTEGRASI VERTIKAL RANTAI NILAI AGROINDUSTRI KAKAO SKALA KECIL
}

\author{
TRANSACTION COST AND BENEFIT COST ON \\ VERTICAL INTEGRATION OF CACAO SMALL SCALE AGROINDUSTRY VALUE CHAIN
}

\author{
Zulfiandri $^{* 11}$, M. Syamsul Maarif**), Aji Hermawan**), Hartrisari Hardjomidjojo ${ }^{* * *)}$ \\ *) Program Studi Teknik Industri, Fakultas Teknik, Universitas Esa Unggul \\ Jalan Arjuna Utara No.9, Kebon Jeruk, Jakarta 11510 \\ ${ }^{* *}$ Sekolah Bisnis, Institut Pertanian Bogor \\ Jl. Raya Pajajaran, Bogor 16151 \\ ${ }^{* * *}$ Departemen Teknologi Industri Pertanian, Fakultas Teknologi Pertanian, Institut Pertanian Bogor \\ Kampus IPB Darmaga, Gedung FATETA Lantai 2, JL. Lingkar Akademik, 16680
}

\begin{abstract}
The government has provided incentives of technology to farmer groups engaged in the business of cocoa and chocolate. The incentives are expected to improve the downstream processes of the agricultural commodities. One downstream strategy developed by the government is developing a small capacity of the cocoa industry to undertake the processing of cocoa beans. The government intends to integrate the aquaculture sector (on-farm) with the processing sector (off-farm). This study aimed to analyze the transaction fee on each cocoa agro-industry value chain and analyze the feasibility of cocoa agro-industry vertical integration with benefit-cost ratio analysis in order to obtain the input vertical integration of agro-industry appropriate for cocoa farmer groups in Indonesia. The research showed that transaction costs increased concurrently with the vertical integration between small-scale cocoa value-chains. The vertical integration showed a positive correlation with the feasibility of cocoa agro-industry. If the business is run separately, it is a worthy effort in the early stage and late stage chains (culinary). If the business is integrated between stage 1 and stage 2, the value of $B C$ ratio is still not feasible. The vertical integration stage 1 , stage 2 and stage 3 cacao of the agro-industry produced a BC ratio of 1.12, indicating that the business is financially feasible.
\end{abstract}

Keywords: cocoa agroindustry, technology incentives, transaction cost, benefit cost analysis, vertical integration

\begin{abstract}
Abstrak: Pemberian insentif teknologi oleh pemerintah kepada kelompok-kelompok tani kakao dan kelompok usaha coklat telah diberikan oleh pemerintah. Salah satu strategi hilirisasi yang dikembangkan pemerintah adalah mengembangkan industri kakao berkapasitas kecil untuk mengolah biji kakao. Pemerintah ingin mengintegrasikan sektor budidaya dengan sektor industri pengolahan. Penelitian ini bertujuan untuk menganalisis biaya transaksi pada setiap rantai nilai agrindustri kakao dan menganalisis kelayakan integrasi vertikal agroindustri kakao dengan Benefit-Cost rasio analisis agar dapat diperoleh masukan integrasi vertikal agroindustri yang tepat bagi kelompok tani kakao di Indonesia. Penelitian menunjukkan bahwa biaya transaksi meningkat seiring dengan terjadinya integrasi vertikal antar rantai nilai kakao skala kecil. Tingginya biaya transaksi pada tahapan agroindustri karena adanya biaya lobby dan penyiapan lahan bagi pabrik mini kakao untuk mendapatkan insentif teknologi dari pemerintah. Integrasi vertikal menunjukkan korelasi positif dengan kelayakan usaha agroindustri kakao. Jika usaha ini dikerjakan secara terpisah maka usaha yang layak pada rantai tahap awal dan tahap akhir (kuliner coklat). Jika usaha ini dintegrasikan antara tahap 1 dan tahap 2, BC rasio belum layak. Integrasi vertikal tahap 1, tahap 2 dan tahap 3 agroindustri kakao memberikan nilai BC rasio 1,12 yang berarti usaha layak secara finansial.
\end{abstract}

Kata kunci: agroindustri kakao, insentif teknologi, biaya transaksi, analisis biaya-manfaat, integrasi vertikal

\footnotetext{
${ }^{1}$ Corresponding author:

Email: zulfiandri@esaunggul.ac.id
} 


\section{PENDAHULUAN}

Indonesia merupakan salah satu dari tiga besar Negara pengekspor kakao dunia. Ekspor kakao Indonesia sebagian besar dalam bentuk biji (bean), sehingga nilai tambah produk ini tidak optimal. Sebagian besar produksi kakao dari Indonesia diekspor. Dari jumlah produksi sebesar 830.790 ton pada 2009, sebesar 439.305 ton untuk diekspor dalam keadaan mentah dan pada tahun 2014 menjadi 728.414 ton dengan jumlah sebesar 333.679 ton diekspor dalam bentuk biji; serta diperkirakan pada tahun 2015 produksi sekitar 661.243 ton dengan jumlah sebesar 355.321 ton diekspor dalam bentuk biji (Pusdatin, 2016). Selebihnya diolah menjadi produk setengah jadi dan sedikit sekali yang diolah menjadi produk akhir. Kondisi ini terjadi karena industri pengolahan kakao kurang berkembang di Indonesia. Dari total ekspor kakao Indonesia, lebih dari $82 \%$ di antaranya berbentuk biji, dan selainnya diekspor dalam bentuk pasta, butter, tepung, dan makanan yang mengandung cokelat. Dalam perdagangan internasional, kakao Indonesia memiliki keunggulan komparatif untuk biji kakao, kakao pasta, lemak kakao maupun bubuk kakao. Namun, masih belum mampu menyaingi negara eksportir lainnya seperti (Malaysia, Jerman, Belanda dan Pantai Gading) di pasar biji kakao maupun olahan (Tresliyana et al. 2015).

Pengolahan hilir kakao merupakan bagian dari pengembangan agroindustri secara keseluruhan. Hilirisasi kakao diharapkan dapat mendorong dan menarik sektor ekonomi lainnya. Sebab, pembangunan agroindustri sangat berkaitan dengan keperluan pengembangan kegiatan ekonomi berbasis pertanian yang berkontribusi terhadap produk domestik regional bruto (PDRB), penyerapan tenaga kerja, menumbuhkan pengusaha kecil-menengah, menarik investor dan devisa ekspor (Iqbal dan Anugerah, 2009). Pengembangan agroindustriberbasis kakao juga mampu mengatasi kesenjangan ekonomi dan mendistribusikan kesejahteraan untuk mengatasi kemiskinan di Indonesia (Sinaga dan Susilowati, 2007).

Salah satu strategi hilirisasi yang dikembangkan oleh pemerintah adalah mengembangkan industri kakao berkapasitas kecil untuk melakukan pengolahan biji kakao. Pemerintah ingin mengintegrasikan sektor budi daya (on-farm) dengan sektor pengolahan (off-farm), agar pengembangan lebih terpadu dan pembinaannya menjadi lebih mudah.Upaya ini merupakan bentuk dari integrasi vertikal usaha kakao. Salah satu alasan pengembangan dengan pendekatan integrasi vertikal adalah agar harga yang diterima oleh petani lebih tinggi. Peningkatan harga yang diterima dengan integrasi vertikal antara rantai penghasil bahan baku dengan konsumen atau pasar (Fischer dan Qaim, 2012), dan meningkatkan posisi tawar petani (Trebbin, 2014). Dengan integrasi vertikal harga dapat ditetapkan pada produk akhir sehingga dapat meningkatkan daya saing produk (Haynes et al. 2012).

Integrasi vertikal menyebabkan terjadinya perubahan kelembagaaan. Proses transformasi ini dimulai dari peran teknopreneur dan pemerintah dalam melakukan perubahan dari lembaga kelompok tani menjadi kelompok agroindustri. Teknopreneur bertindak sebagai agen perubahan internal sedangkan pemerintah memberikan insentif teknologi agar proses perubahan terjadi (Zulfiandri et al. 2017). Efektifitas perubahan kelembagaan dalam rantai nilai perlu diukur. Ruttan dan Hayami (1984) menyatakan bahwa perubahan kelembagaan selalu dikaitkan dengan keuntungan yang akan dinikmati oleh pelaku yang terlibat di dalamnya. Artinya, perubahan perubahan kelembagaan memiliki keuntungan jika biaya-biaya yang muncul lebih kecil dari manfaat yang diterima. Setiap transaksi dalam kegiatan ekonomi memiliki cara perhitungan dan definisi tentang biaya transaksi.

Biaya transaksi merupakan biaya yang muncul akibat adanya transaksi (biaya atas lahan, tenaga kerja, kapital dan keterampilan kewirausahaan untuk memindahkan secara fisik input menjadi output (Yustika, 2007). Biaya transaksi merupakan biaya yang timbul dari proses antara yang terjadi untuk memberikan/mentransfer hak (right) dari satu pihak kepada pihak lain. Biaya transaksi muncul akibat adanya ketidakpastian di pasar seperti informasi yang tidak sempurna dan rasionalitas para pelaku yang terbatas. Didalam teori New Instutional Economic, dihadirkanlah peran institusi sebagai wujud pengendalian dari kondisi ekonomi yang ada. Institusi bertujuan untuk memfasilitasi tiap individu yang bergabung untuk menghadapi kondisi pasar yang ada sehingga tercipta transaksi yang efektif dan efisien (Williamson, 1985). Kelembagaan sebagai suatu wadah yang terikat aturan formal diharapkan mampu menekan biaya transaksi sesuai dengan fungsi aturan fomal atau informal (institusi) yang berperan untuk membantu para pelaku pertukaran dalam menghadapi ketidakpastian di pasar ekonomi (North, 1990; Williamson, 1985). 
Selain dengan melihat biaya transaksi, dari setiap perubahan kelembagaan, integrasi vertikal juga dapat dianalisis dengan analisis biaya manfaat. Analisis biaya manfaat merupakan suatu metode pendekatan dengan proses yang sistematis dengan cara membandingkan antara manfaat dengan biaya dalam mengevaluasi manfaat suatu proyek atau program yang bersifat sosial (Hanley et al. 2009). Metode ini dipakai untuk menjawab pertanyaan apakah proyek yang diusulkan memiliki manfaat, skala optimal dari integrasi yang diusulkan dan kendala yang relevan. Selanjutnya, dari hasil ini untuk para pengambil keputusan mampu membuat pertimbangan apakah suatu proyek dilanjutkan atau tidak, suatu produk atau proyek, atau dalam konteks kelembagaan yang mengalami suatu perubahan baik yang telah berjalan atau akan berjalan. Agar strategi hilirisasi yang menjadi program pemerintah Indonesia dapat berjalan efektif maka perlu diketahui strategi integrasi vertikal yang terbaik.

Penelitian ini bertujuan menganalisis biaya transaksi pada setiap rantai nilai agrindustri kakao dan menganalisis kelayakan integrasi vertikal agroindustri kakao dengan Benefit-Cost rasio analisis. Manfaat dari penelitian adalah agar diperoleh masukan dalam pengembangan integrasi vertikal agroindustri yang tepat bagi kelompok tani kakao di Indonesia. Batasan penelitian tentang integrasi vertikal yang dimaksud adalah integrasi yang dilakukan pada rantai budi daya kakao sampai menjadi biji kakao kering yang telah difermentasi, industri pengolahan primer, industri pengolahan coklat dan industri kuliner berbahan baku coklat. Skala industri pada penelitian ini berskala kecil.

\section{METODE PENELITIAN}

Penelitian ini terdiri atas dua kegiatan yang dilakukan secara simultan. Pertama, pengumpulan data dan informasi serta analisis biaya transaksi. Data yang dikumpulkan terdiri atas data primer dan sekunder. Data primer berupa data biaya transaksi kemudian sebagiannya menjadi data dan informasi untuk analisis biaya-manfaat selain data biaya yang bukan biaya transaksi serta manfaat yang dimiliki. Hasil analisis ini memiliki implikasi manajerial yang harus diambil dan dilakukan oleh pemerintah sebagai pihak yang paling memiliki kepentingan dalam pengembangan agroindustri kakao dan pelaku usaha terutama petani kakao dan pengusaha industri pengolahan dalam rangka program kemitraan.

Rantai nilai global kakao-coklat di Indonesia secara umum dapat digambarkan seperti pada Gambar1 di bawah ini. Rantai nilai ini menggambarkan pemberian nilai tambah yang diberikan sepanjang rantai industri kakao menjadi pangan coklat. Rantai nilai industri kakao dari Gambar 1, berdasarkan beberapa hasil penelitian sebelumnya, mulai dari rantai nilai kakao dari petani ke konsumen akhir yang melalui tahapan produksi, perdagangan biji kakao, pengolahan biji kakao (industri primer), pengolahan coklat, distribusi dan ritel (Normansyah, 2013; Sriwana et al. 2014; Putri et al. 2015; Ambarawati et al. 2015). Agar strategi hilirisasi yang menjadi program pemerintah Indonesia dapat berjalan efektif maka perlu diketahui strategi integrasi vertikal yang terbaik.

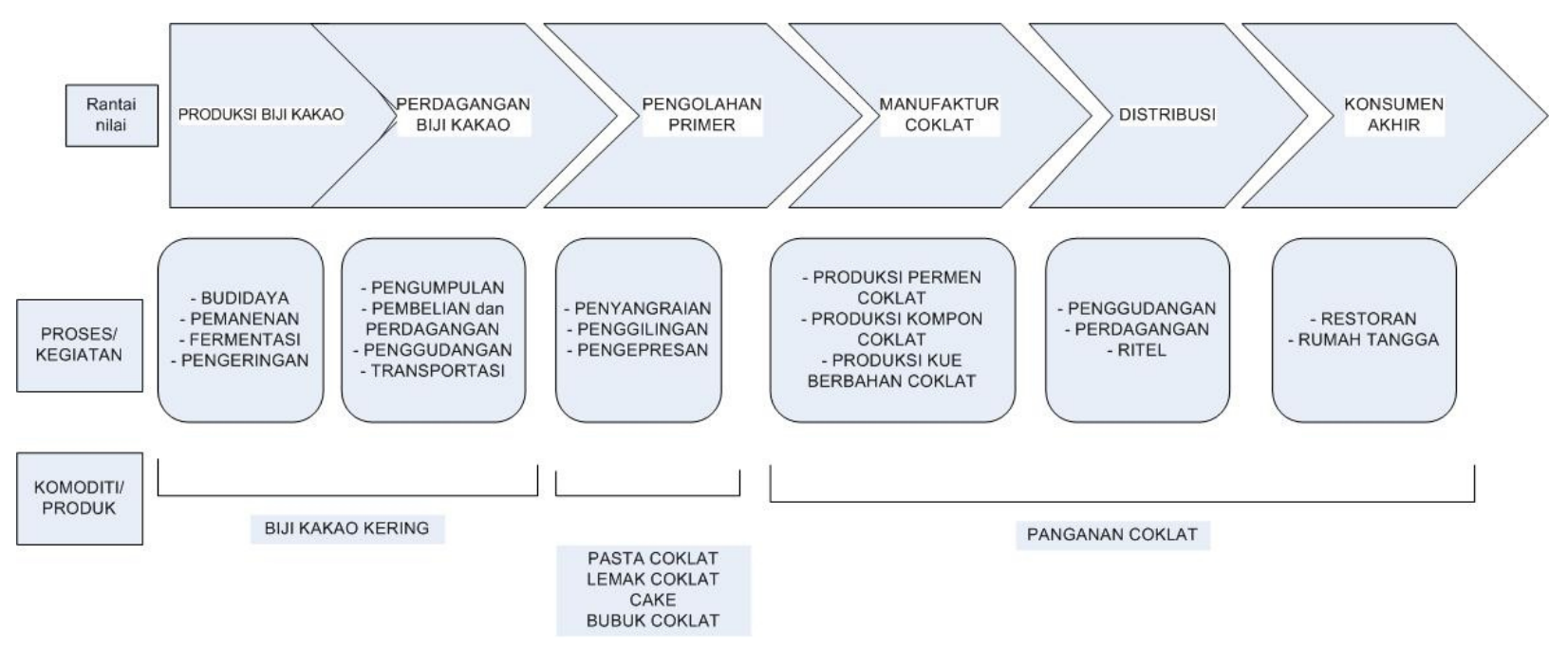

Gambar 1. Rantai nilai industri kakao-coklat di Indonesia (Rifin 2005; Normansyah, 2013; Sriwana et al. 2014; Putri et al. 2015; Ambarawati et al. 2015). 
Data primer diperoleh dari hasil survei dengan menggunakan kuesioner dan wawancara secara mendalam terhadap para responden, yaitu ketua dan anggota kelompok tani kakao Tanjung Subur, Kecamatan Payakumbuh Selatan, Kota Payakumbuh, Adam Coklat, di Kecamatan 2 x 11 Enam Lingkung, Kabupaten Pariaman Sumatera Barat di Sumatera Barat; Subak Abian Padma Sari, Desa Nusa Sari, Kabupaten Jembrana, Bali; industri kecil menengah (IKM) coklat di Kota Padang dan dan Kendari. Kelompok tani yang dipilih adalah kelompok tani yang anggotanya telah menghasilkan biji kakao fermentasi. Data sekunder seperti harga biji kakao dan produk agroindustri kakao diperoleh dari berita perdagangan kakao, publikasi Dinas Perindustrian dan Perdagangan Provinsi Sumatera Barat dan Sulawesi Tenggara, dan Dinas Perkebunan di Provinsi Sumatera Barat. Data sekunder juga diperoleh dari publikasi berupa laporan, data stastistik, profil kelompok tani kakao.

\section{Biaya Transaksi}

Perhitungan biaya transaksi dalam konteks mikro atau level perusahaan mengikuti berdasarkan kerangka kerja dari Chen (2010) dan Dann (2010) yang secara umum mengkategorikan biaya transaksi dalam integrasi vertikal rantai pasok secara umum merupakan biaya yang dikeluarkan oleh perusahaan atau organisasi untuk mempertahankan rantai pasok yang efesien. Biaya tersebut bisa termasuk variabel biaya organisasi tenaga kerja, biaya koordinasi pemasok (biaya-biaya akuisisi pemasok), biaya meotivasi pelanggan, biaya mengelola distributor, biaya memuaskan pemegang saham dan kreditur, biaya komisi, pajak dan fee, biaya penelitian dan pengembangan, biaya-biaya penjualan dan biaya laporan neraca keuangan. Pada intinya biaya-biaya yang didapatkan di lapangan sebagai biaya transaksi adalah biaya yang muncul agar terjadi pertukaran (exchange) (Yustika, 2007; Williamson, 2010).

Total biaya transaksi yang dihadapi oleh kelompok tani kakao dalam integrasi vertikal dengan agroindustri kakao dihitung dengan menggunakan persamaan :

$$
\operatorname{TrC}_{\mathrm{j}}=\Sigma \mathrm{Z}_{\mathrm{ij}}
$$

Keterangan: $Z_{\mathrm{ij}}$ (Unit komponen biaya transaksi); $\operatorname{TrC}_{\mathrm{j}}$ (Total biaya transaksi pada integrasi vertikal j)

\section{Analisis Biaya-Manfaat (Benefit-Cost Analysis)}

Perhitungan Benefit-Cost Analysis (BCA) didasarkan pada panduan Commonwealth of Australia (2006) dan pendapat dari (Hanley et al. 2009) dengan langkah penting BCA sebagai berikut:

1. Mendeskripsikan input dan output program secara kuantitatif, dalam hal ini perubahan kelembagaan yang terjadi.

2. Estimasi biaya dan manfaat sosial dari input dan output. Seluruh manfaat dan biaya dalam BCA harus dinyatakan dalam bentuk nilai uang atau moneter agar bias dibandingkan secara langsung. Namun, seringkali penilai harus berhadapan dengan manfaat dan atau biaya yang tidak memiliki nilai pasar (intangible) sehingga harus dilakukan estimasi dengan teknik-teknik valuasi kelembagaan. Jika penilaian kuantitatif tidak dapat dilakukan maka dapat dijelaskan secara kualitatif dan kuantifikasi seoptimal mungkin, dan mendokumentasikan alasan mengapa manfaat tidak dapat dimonetasi.

3. Menghitung criteria performa dari program atau perubahan kelembagaan, yaitu a) Menghitung nilai komponen biaya. Biaya-biaya di atas akan didapatkan dari data sekunder kelompok tahun nol perubahan kelembagaan atau sebelum insentif teknologi diberikan pemerintah kepada kelompok. b) Menghitung Nilai Komponen Manfaat. Manfaat yang di hitung adalah manfaat yang langsung dan tidak langsung yang bisa dinilai. Manfaat yang tidak bisa dinilai secara kuantitatif tidak termasuk dalam komponen manfaat. c) Menilai Kelayakan Integrasi Vertikal. Kriteria kelayakan program dengan $\mathrm{BC}$ rasio. Metode ini merupakan metode yang menghitung perbandingan antara manfaat dengan biaya. Rumus yang digunakan untuk menghitung Benefit Cost Ratio (BCR) sebagai berikut:

$$
B C R=\frac{\sum_{t=0}^{n} \frac{B t}{(1+r)^{t}}}{\sum_{t=0}^{n} \frac{C t}{(1+r)^{t}}}
$$

Keterangan: $\mathrm{r}$ (discount rate yang digunakan); $\mathrm{Bt}$ (Manfaat pada periode t); Ct (Biaya pada periode t); $\mathrm{n}$ (periode yang terakhir dimana cash flow diharapkan).

Apabila proses suatu investasi tidak sama besarnya dari tahun ke tahun maka harus menghitung present value dari proses setiap tahunnya terlebihdahulu untuk dijumlahkan sehingga diperoleh jumlah present 
value dari keseluruhan proceeds yang diharapkan dari investasi. Kriteria kelayakan penerimaan investasi menggunakan metode BCR adalah suatu investasi yang diusulkan dinyatakan layak jika BCR lebih besar dari satu. Sebaliknya, jika BCR suatu investasi lebih kecil dari satu maka investasi tersebut dinyatakan tidak layak (Hanley et al. 2009).

\section{HASIL}

\section{Biaya Transaksi}

Biaya transaksi merupakan biaya yang dikeluarkan oleh lembaga agar terjadi pertukaran. Secara konseptual biaya transaksi diperkenalkan oleh Ronald Coase. Biaya transaksi yakni biaya yang timbul dalam mengkoordinasikan aktivitas ekonomi yang menggunakan mekanisme harga. Biaya-biaya (costs) yang dikeluarkan ini dapat berupa waktu maupun sumberdaya yang biasanya diukur/dikonversikan dengan satuan mata uang dalam melaksanakan suatu transaksi (pertukaran hak kepemilikan) yang berupa barang, jasa maupun hak intelektual (Coase, 1937). Keputusan untuk melangsungkan transaksi pada sebuah unit usaha atau pasar ditentukan oleh biaya transaksi, dan biaya transaksi sangat beragam baik jenis dan sumbernya. Pada penelitian ini kajian biaya transaksi dilakukan pada dimasing-masing integrasi vertikal yang dilakukan oleh kelompok petani kakao dengan industri pengolahan biji kakao fermentasi berskala kecil dan industri pengolahan coklat berskala kecil.

Pada penelitian ini yang struktur biaya yang dianalisis adalah biaya transaksi yang terbentuk pada:

1. Rantai budi daya kakao (produk: biji kakao fermentasi)

2. Rantai budi daya kakao dengan industri pengolahan biji kakao kering/agroindustri tahap 1 (produk: pasta coklat, lemak coklat dan bubuk coklat)

3. Rantai budi daya kakao, agroindustri tahap 1 dengan agroindustri hilir kakao/agroindustri tahap 2 (produk: permen coklat, bubuk coklat mix, kuliner berbahan dasar coklat)

4. Rantai budi daya kakao - agroindustri tahap 1 agroindustri tahap 2 dengan agroindustri kreatif/ kuliner berbahan baku coklat (cafe coklat, rumah coklat, dan lain-lain).
Tahap 1: budi daya kakao (produk: biji kakao fermentasi). Pada tahap rantai budi daya kakao, biaya yang muncul agar terjadi pertukaran di pasar adalah biaya yang berhubungan dengan proses produksi biji kakao basah menjadi biji kakao kering fermentasi. Agar kelompok tani bisa bernegosiasi dengan lembaga usaha seperti dengan pihak industri pengolahan pada umumnya kelompok tani menggunakan badan usaha bebentuk koperasi. Kelompok tani Tanjung Subur, Kelurahan Kapalo Koto, Payakumbuh menggunakan badan hukum koperasi sebagai lembaga usaha. Koperasi Tanjung Subur memiliki divisi agroindustri yang mengelola pabrik mini kakao. Subak Abian Padma Sari menggunakan badan hukum Koperasi Kerta Semaya Samaniya sebagai lembaga usaha untuk bernegosiasi dengan pihak industri.

Besarnya biaya transaksi pada tahap ini adalah Rp8.416.667/bulan. Biaya-biaya yang muncul berasal dari biaya pembentukan koperasi, untuk transportasi dan rapat pembentukan koperasi (Rp500.000/bulan); biaya sosialisasi dan pelatihan fermentasi biji kakao yang baik untuk anggota kelompok (Rp1.166.667/ bulan); biaya untuk internal control system (ICS) yang melakukan proses pengawasan dan penjamin mutu biji kakao fermentasi di dalam internal kelompok/ koperasi (Rp833.333/bulan); biaya sertifikasi biji kakao fermentasi (Rp3.916.667/bulan); biaya logistik biji kakao fermentasi, seperti biaya transportasi dan gudang (Rp2.000.000/bulan). Biaya transaksi paling besar pada tahap awal rantai pasok agroindutsri kakao adalah biaya sertifikasi biji kakao fermentasi. Sertifikat ini diperlukan agar produsen biji kakao bisa diterima oleh industri. Koperasi atau kelompok tani melakukan sertifikasi biji kakao hasil produksi anggotanya dengan sertifikat yang diakui oleh negara importir seperti sertifikasi UTZ untuk biji kakao fermentasi. Biaya sertifikasi ini mencapai $45,5 \%$ dari biaya transaksi yang harus dikeluarkan oleh kelompok tani atau koperasi. Biaya sertifikasi total yang dikeluarkan oleh petani kakao di Jembrana Rp47 juta/tahun. Biaya ini bisa ditanggulangi atau dibayarkan oleh pemerintah melalui Pemerintah Kabupaten Jembrana sebagai salah satu bentuk insentif dari pemerintah. Insentif yang diberikan oleh pemerintah ini merangsang petani untuk menghasilkan biji kakao fermentasi, selain harga pembelian premium yang diberikan oleh industri. Pemberian insentif kepada petani dapat membangkitkan minat menjadi petani. Insentif ini tidak hanya yang langsung diberikan untuk menghasilkan komoditas pertanian, tetapi dapat juga secara tidak langsung 
namun berdampak kepada kesejahteraan petani; seperti insentif pada biaya transportasi hasil panen atau berupa persiapan pensiun di hari tua sebagai petani, dimana pemeirntah memberikan subsidi khusus dalam skema pembiayaan hari tua bagi petani (Davis et al. 2013).

Tahap 2: agroindustri tahap 1

Pada tahap integrasi vertikal ini, terjadi penggabungan rantai pasok suplai biji kakao kering dengan industri pengolah biji kakao kering. Produk yang dipertukarkan pada tahap ini merupakan olahan biji kakao kering menjadi pasta coklat, lemak coklat dan bubuk coklat.

Besarnya biaya transaksi pada tahap ini adalah Rp35.545.333/bulan. biaya-biaya yang muncul berasal dari biaya selisih harga pembelian biji kakao dari petani dengan harga pasar (Rp15.000.0000/bulan; biaya insentif teknologi yang terdiri atas biaya lobby ke pemerintah dan biaya sewa lahan pabrik serta biaya konstruksi pabrik (Rp4.032.500/bulan); biaya produksi untuk biaya SDM, biaya energi/listrik, dan biaya pemeliharaan mesin dan bangunan pabrik (Rp13.313.333/bulan); dan biaya pemasaran yang terdiri atas biaya transportasi, biaya penyimpanan produk, fee marketing (Rp3.200.000/bulan). Biaya yang muncul dari tahap ini yang merupakan integrasi atau penggabungan rantai pasok dengan industri yang dimiliki sendiri oleh kelompok tani atau koperasi. Sehingga biaya-biaya yang muncul dalam rangka terjadinya pertukaran adalah biaya pengadaan bahan baku dan biaya-biaya yang muncul agar produk tersedia dan siap dikirim ke pasar. Biaya pengadaan bahan baku yang dihitung adalah harga antara harga pasar atau dibeli dari pedagang pengumpul dengan harga pembelian langsung ke petani, karena industri dimiliki oleh koperasi atau kelompok tani. Biaya yang terjadi agar produk industri bisa eksis adalah biayabiaya yang muncul agar pemerintah mau memberikan insentif teknologi kepada kelompok, biaya produksi dan biaya pemasaran produk. Biaya untuk mendapatkan insentif teknologi dari pemerintah tersebut diantaranya biaya akuisisi lahan pabrik mini, biaya lobby ke pihak pemerintah oleh kelompok atau koperasi dan biaya kontruksi bangunan pabrik mini. Biaya produksi yang dimasukkan sebagai biaya transaksi adalah biaya tenaga kerja, pajak, biaya pemeliharan alat dan mesin produksi dan biaya energi/listrik pabrik mini kakao. Biaya yang termasuk biaya pemasaran adalah biaya trasnportasi, biaya penyimpanan produk dan biaya fee-marketing.
Tahap 3: agroindustri tahap 2

Pada tahap integrasi vertikal ini, terjadi penggabungan rantai pasok suplai biji kakao kering dan industri pengolah biji kakao kering dengan industri pengolahan produk kakao. Produk yang dipertukarkan pada tahap ini merupakan olahan produk kakao menjadi produk panganan dan bahan nonpangan berbasis coklat seperti permen coklat, minuman coklat, dan lulur coklat.

Besarnya biaya transaksi pada tahap ini menurun menjadi Rp27.605.000/bulan, biaya-biaya ini terdiri atas biaya suplai bahan baku produksi baik bahan utama, penolong maupun bahan kemasan (Rp18.250.000/ bulan); biaya insentif teknologi yang terdiri atas biaya lobby ke pemerintah dan biaya konstruksi pabrik (Rp1.666.667/bulan); biaya produksi yang terdiri atas biaya SDM, biaya energi/listrik, biaya pemeliharan (Rp4.133.333/bulan); biaya perijinan dan sertifikasi baik sertifikat halal, sertifikat SNI dan ijin edar dari Badan POM(Rp3.125.000/bulan); dan biaya pemasaran (Rp450.000/bulan). Biaya yang muncul dari tahap ini yang merupakan integrasi atau penggabungan rantai pasok dengan agroindustri yang dimiliki sendiri oleh kelompok tani atau koperasi. Oleh karena itu, biayabiaya yang muncul dalam rangka terjadinya pertukaran adalah biaya pengadaan bahan penolong termasuk bahan kemasan dan biaya-biaya yang muncul agar produk tersedia dan siap dikirim ke pasar. Biaya yang terjadi agar produk industri bisa eksis adalah biaya-biaya yang muncul agar pemerintah mau memberikan insentif teknologi kepada kelompok, biaya produksi dan biaya pemasaran produk. Biaya untuk mendapatkan insentif teknologi dari pemerintah tersebut diantaranya biaya konstruksi tambahan pabrik mini dan biaya lobby ke pihak pemerintah oleh kelompok atau koperasi. Biaya produksi yang dimasukkan sebagai biaya transaksi adalah biaya tenaga kerja, biaya pemeliharan alat dan mesin produksi dan biaya energi/listrik pabrik mini kakao. Biaya yang termasuk biaya pemasaran adalah biaya trasnportasi, biaya penyimpanan produk dan biaya fee-marketing.

\section{Tahap 4: agroindustri tahap 3}

Pada tahap integrasi vertikal ini, terjadi penggabungan rantai pasok suplai biji kakao kering dan industri pengolah biji kakao kering sekaligus industri pengolahan produk kakao dengan agroindustri kreatif/ kuliner berbahan baku coklat (cafe coklat, rumah coklat, dan lain-lain). Produk yang dipertukarkan pada 
tahap ini merupakan olahan produk coklat menjadi produk jasa kuliner panganan berbasis coklat seperti kue coklat, makanan dan minuman dari coklat.

Pada tahap ini biaya transaksi yang muncul berdasarkan hasil wawancara dan kuesioner adalah Rp13.416.667/ bulan, yang terdiri biaya suplai bahan baku berupa makanan dan minuman berbasis coklat (Rp5.000.000/ bulan); biaya produksi yang terdiri atas biaya SDM, dan biaya energi/listrik (Rp4.000.000/bulan); biaya perijinan dan sertifikasi (Rp4.166.667/bulan); dan biaya pemasaran (Rp250.000/bulan). Biaya yang muncul dari tahap ini yang merupakan integrasi atau penggabungan rantai pasok dengan industri kuliner yang dimiliki sendiri oleh kelompok tani atau koperasi. Biaya-biaya yang muncul dalam rangka terjadinya pertukaran adalah biaya pengadaan bahan baku dan biaya-biaya yang muncul agar produk tersedia dan siap dikonsumsi oleh konsumen akhir. Biaya yang terjadi agar produk industri tahap ini bisa terjadi adalah biaya produksi dan biaya pemasaran produk. Biaya produksi yang dimasukkan sebagai biaya transaksi adalah biaya tenaga kerja, dan biaya internet dan energi/listrik kafe restoran coklat. Sementara itu, biaya pemasaran yang termasuk biaya transaksi adalah biaya promosi.

Biaya transaksi paling tinggi terjadi pada tahap 2, yakni tahap agroindustri pengolahan biji kakao dengan produk yang dihasilkan adalah pasta kakao, lemak dan bubuk coklat. Tingginya biaya transaksi pada tahap ini karena adanya biaya lobby ke pemerirntah untuk memperoleh insentif teknologi, dan biaya pembebasan lahan atau biaya sewa lahan pabrik yang tidak termasuk ke dalam insentif teknologi yang diberikan pemerintah. Biaya transaksi ini kemudian turun pada tahap 3 dan tahap 4 . Gambar 2 berikut menampilkan biaya transaksi pada setiap tahap integrasi vertikal.

\section{Analisis Biaya Manfaat}

Asumsi makro ekonomi yang mendasari perhitungan analisis biaya manfaat ini adalah tingkat suku bunga $12 \%$, tingkat inflasi $6 \%$ dan pajak sebesar $15 \%$. Asumsi lainnya adalah peningkatan kenaikan harga sebesar 4\% pertahun, biaya pemeliharaan kantor dan mesin rata-rata sebesar 1\% per tahun dan penyusutan dihitung dengan metode garis lurus dan pabrik beroperasi selama 300 hari dalam setahun. Komponen biaya manfaat terdiri atas komponen biaya dan manfaat. Komponen biaya terdiri atas biaya investasi dan biaya operasional.

Biaya investasi lahan dan peralatan untuk tahap rantai pasok biji kakao fermentasi diasumsikan tidak ada. Biaya-biaya yang muncul adalah biaya operasional langsung, biaya sertifikasi dan biaya-biaya pengelolaan koperasi. Besaran biaya tersebut masing-masing adalah biaya sertifikasi dan pengelolaan lembaga Rp100 juta/ tahun, dan biaya operasional langsung sebesar Rp180 juta/tahun. Harga rata-rata biji kakao fermentasi kering pada saat penelitian sebesar Rp 32.000/kg di tingkat petani dan $\mathrm{Rp} 43.000 / \mathrm{kg}$ di tingkat pedagang pengumpul. Harga biji kakao non fermentasi di tingkat petani sebesar Rp29.000/kg. Pada tahun-tahun awal diasumsikan koperasi hanya mampu menjual sekitar 2 ton biji kakao fermentasi dan nonfermentasi, kemudian jumlah ini meningkat terus seiring dengan kesadaran petani untuk menjual biji kakao melalui koperasi, kemudian koperasi melakukan proses fermentasi secara terpusat. Berdasarkan perhitungan, nilai $\mathrm{BC}$ ratio pada tahap ini adalah sebesar 1,21. Artinya, pada tahap ini usaha yang dijalankan kelompok dalam bentuk koperasi dengan menjual biji kakao fermentasi dan non fermentasi layak secara bisnis.

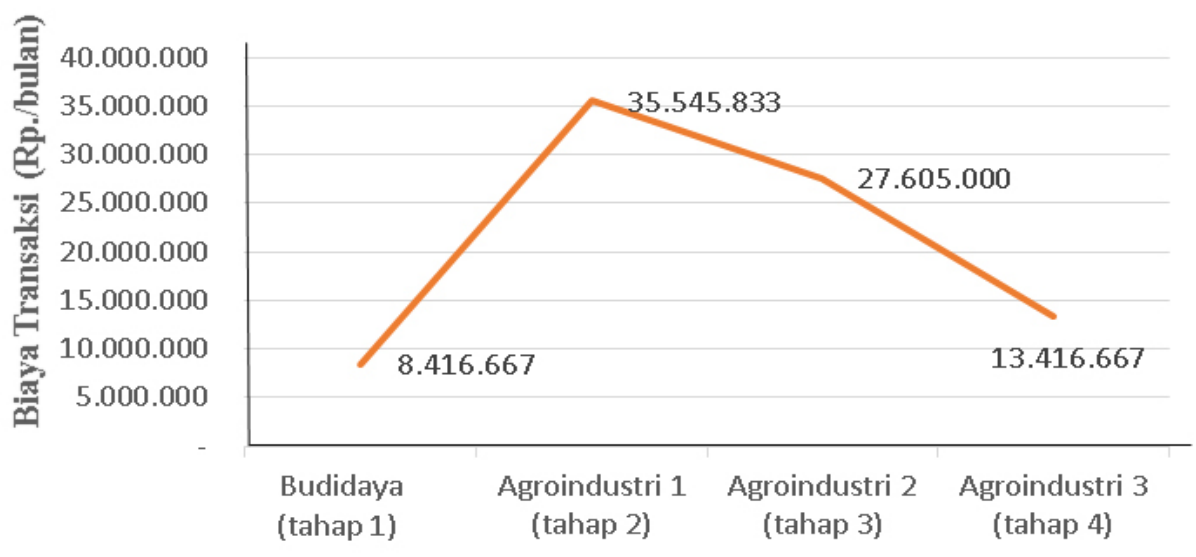

Tahapan Rantai Nilai

Gambar 2. Grafik biaya transaksi total pada integrasi vertikal agroindustri kakao 
Pada tahap agroindustri pengolahan kakao menjadi pasta, lemak dan bubuk kakao, biaya invetasi terdiri atas mesin-mesin dan peralatan pabrik (Rp315,5 juta dengan umur ekonomis 20 tahun), biaya sertifikasi dan perijinan (Rp5 juta/tahun), dan biaya konstruksi bangunan pabrik (Rp. 293,9 juta dengan umur ekonomis 20 tahun). Biaya operasional terdiri atas biaya pembelian bahan baku, biaya energi, biaya SDM dan biaya bahan pembantu Rp561.805.714/tahun), biaya penyusutan (Rp21.033.333/tahun)), biaya pemeliharaan mesin dan bangunan pabrik (Rp3.760.000/tahun), pajak (Rp6.252.000/tahun). Manfaat yang diperoleh dari industri kecil pengolahan kakao ini secara langsung adalah penjualan produk hasil industri, yakni pasta coklat dengan harga Rp50.000/kg, bubuk coklat (Rp60.000/kg) dan lemak coklat (Rp80.000). Kapasitas produksi industri berkisar $300 \mathrm{~kg}$ biji coklat kering per hari. Efisiensi mesin mengolah biji kakao menjadi kakao pasta berkisar $70 \%$. Berdasarkan perhitungan, nilai BC ratio pada tahap ini adalah sebesar 0,84 . Artinya, pada tahap ini usaha agroindustri yang dijalankan kelompok tidak layak secara bisnis. Jika biaya investasi dianggap tidak ada, karena mesin-mesin dan peralatan merupakan bantuan dari pemerintah maka nilai $\mathrm{BC}$ ratio pada tahap ini adalah sebesar 0,87 yang tetap tidak layak secara bisnis. Tidak layaknya usaha pada tahap ini, disebabkan karena skala usaha yang sangat kecil pada kemampuan mesin pengepres sehingga skala usaha tidak tercapai.

Pada tahap agroindustri pengolahan kakao menjadi pasta, lemak dan bubuk kakao, biaya invetasi terdiri atas mesin-mesin dan peralatan pabrik (Rp183.250.000 dengan umur ekonomis 20 tahun), biaya dan sertifikasi (Rp65.000.000), biaya konstruksi bangunan dan sipil (Rp100.000.000 dengan umur ekonomis 20 tahun). Biaya operasional terdiri atas biaya bahan baku, energi, SDM (Rp803.518.000/tahun), biaya depresiasi (Rp12.216.667/tahun), biaya pemeliharaan (Rp3.760.000/tahun) dan pajak (Rp1.086.600/tahun). Manfaat yang diperoleh secara langsung adalah penjualan permen coklat (Rp288.000/kg), coklat kompon (Rp50.000/kg), lulur coklat (Rp150.000/ $\mathrm{kg})$, coklat 3 in $1(\mathrm{Rp} 200.000 / \mathrm{kg})$ dan coklat jahe (Rp180.000/kg). Berdasarkan perhitungan, nilai BC ratio pada tahap ini adalah sebesar 0,97. Artinya, pada tahap ini usaha agroindustri yang dijalankan kelompok tidak layak secara finansial. Jika biaya investasi dianggap tidak ada, karena mesin-mesin dan peralatan merupakan bantuan dari pemerintah maka nilai $\mathrm{BC}$ ratio pada tahap ini adalah sebesar 1,01 yang layak secara bisnis. Tidak layaknya usaha pada tahap ini, disebabkan karena skala usaha yang sangat kecil yang belum mampu mencukup skala ekonomis. Jika mesin dan peralatan dianggap sebagai insentif percuma dari pemerintah, maka kelayakan usaha pada tahap ini layak.

Pada tahap selanjutnya, agroindustri kakao menjadi makanan dan minuman serta kuliner dari coklat biaya investasi untuk peralatan cafe dan restoran (Rp74.000.000 setiap 10 tahun), biaya sertifikasi dan perijinan (Rp52.500.000/tahun), biaya konstruksi bangunan kafe dan kantor (Rp480.000.000 dengan umur ekonomis 20 tahun). Biaya operasional terdiri atas biaya SDM, listrik dan internet serta coklat minuman dan makanan (Rp803.518.800/tahun), biaya penyusutan (Rp4.933.333/tahun), biaya pemeliharaan (Rp3.760.000/tahun), dan pajak (Rp10.500.000/tahun). Komponen manfaat adalah penjulanan makanan dan minuman, masing rata-rata berharga Rp10.000 dan Rp15.000/porsi. Berdasarkan perhitungan, nilai BC ratio pada tahap ini adalah sebesar 1,31. Artinya, pada tahap ini usaha agroindustri yang dijalankan kelompok ini layak secara finansial.

Analisis selanjutnya adalah melihat kelayakan jika masing-masing tahapan di atas diintegrasikan. Secara umum biaya-biaya yang muncul hampir sama kecuali ada pengurangan untuk biaya operasional karena adanya efisiensi penggunaan SDM dan biaya pemeliharaan. Dari sisi manfaat terdapat penambahan yang terjadi karena adanya integrasi vertikal. Manfaat-manfaat yang teridentifikasi dari integrasi ini adalah manfaat limbah sisa fermentasi kakao untuk menjadi pupuk organik, dan biji kakao yang tidak dapat difermentasi bisa dijual oleh kelompok. Manfaat yang bisa dimonetisasikan adalah pelatihan-pelatihan yang dilaksanakan kepada anggota kelompok dan masyarakat umum yang ingin belajar pengolahan kakao dari fermentasi biji kakao sampai pembuatan permen coklat. Selain manfaat yang bisa dihitung terdapat juga manfaat yang tidak dapat dimonetisasikan sebagai tempat Praktek dan Kerja Lapangan (PKL) dan penelitian untuk mahasiswa dan pelajar, meningkatkan ilmu pengetahuan para petani dan meningkatkan bargaining atau reputasi kelompok di mata masyarakat, mitra dan pemerintah.Secara lengkap hasil perhitungan analisis biaya-manfaat integrasi vertikal yang terjadi ditampilkan pada Tabel 5 . 
Tabel 5. Hasil perhitungan integrasi vertikal agroindustri kakao skala kecil

\begin{tabular}{|c|c|c|c|c|}
\hline \multirow{2}{*}{ Tolok Ukur } & \multicolumn{4}{|c|}{ Tahapan Proses Agroindustri Kakao } \\
\hline & Tahap 1 & Tahap 2 & Tahap3 & Tahap 4 \\
\hline Produk & Biji kakao fermentasi & $\begin{array}{l}\text { Pasta coklat } \\
\text { Lemak coklat } \\
\text { Bubuk coklat }\end{array}$ & $\begin{array}{l}\text { Permen coklat } \\
\text { Bubuk coklat campur } \\
\text { Kompon coklat } \\
\text { Lulur coklat }\end{array}$ & Kuliner coklat \\
\hline Tanpa Integrasi & 1,21 & 0,84 & 0,97 & 1,31 \\
\hline Integrasi I & \multicolumn{2}{|c|}{0,96} & 0,97 & 1,31 \\
\hline Integrasi II & \multicolumn{3}{|c|}{1,12} & 1,31 \\
\hline Integrasi III & \multicolumn{4}{|c|}{1,29} \\
\hline
\end{tabular}

Dari Tabel 5, integrasi vertikal antara pemasok bahan baku biji kakao (tahap 1) dengan industri pengolahan (tahap 2) menunjukkan nilai BC rasio 0,96. Penggabungan tahap 1 dan tahap 2 tersebut belum layak secara finansial. Seperti juga tahap 2 secara terpisah, yang tidak layak, kapasitas mesin pengolah yang kecil mengakibatkan usaha telah diintegrasikan ini juga tidak mampu mencapai skala keekonomian usaha. Pada tahap integrasi berikutnya antara tahap 1, tahap 2 dan tahap 3 diintegrasikan, menunjukkan nilai $\mathrm{BC}$ rasio 1,12. Hal ini menunjukkan bahwa usaha ini layak secara keuangan. Demikian juga, jika diintegrasikan dengan tahap ke 4 dari rantai nilai agroindustri kakao. Integrasi vertikal tidak selalu menguntungkan, tergantung kepada jenis bisnis dan tingkat integrasinya. Integrasi vertikal membutuhkan biaya investasi yang cukup tinggi sehingga bagi beberapa bisnis cukup lama untuk menghasilkan profit bagi bisnis (Buzzel, 1983).

\section{Implikasi Manajerial}

Hasil penelitian menunjukkan bahwa pengolahan agroindustri kakao secara terpisah kecuali industri kuliner belum layak secara finansial. Kapasitas pengolahan dan biaya operasional terutama biaya energi yang mahal menjadi penghambat pengembangan industri pengolahan kakao. Insentif teknologi yang diberikan pemerintah kepada kelompok tanikakao harus memperhatikan sisi skala kelayakan usaha. Pemberian insentif kepada kelompok tani berupa mesin-mesin dan peralatan pengolahan kepada kelompok tani kakao harus diintegrasikan secara vertikal dengan agroindustri hilirnya minimal sampai kepada pengolahan coklat. Biaya transaksi yang muncul pada masing-masing mata rantai nilai agroindustri ini juga menunjukkan bahwa biaya transaksi meningkat dengan adanya kegiatan industri pengolahan kakao. Biaya transaksi tertinggi terdapat pada industri tahap 2 dan tahap 3 . Dengan demikian integrasi vertikal harus dilakukan agar kelompok tani memiliki kendali terhadap hasil produknya. Integrasi vertikal ke depan adalah upaya untuk memperoleh kendali terhadap produknya.

Secara kelembagaan peran pemerintah dan dorongan dari pengusaha yang bermitra dalam kelompok tani perlu menjadi pertimbangan agar integrasi vertikal ini bisa berjalan dengan baik. Pengembangan agroindustri dengan pola terpadu layak dijalankan dengan tujuan utama adalah meningkatkan pendapatan petani dan kesejahteraan anggota, dengan memperhatikan aspek permintaan pasar, peran pengusaha untuk berinvestasi, menjalin kemitraan dalam hal pemasaran produk melalui suatu hubungan yang harmonis serta terintegrasi.

\section{KESIMPULAN DAN SARAN}

\section{Kesimpulan}

Biaya transaksi yang muncul dari integrasi vertikal agroindustri kakao skala kecil ini pada tahap rantai budi daya kakao yang menghasilkan produk biji kakao fermentasi) adalah sebesar Rp8.416.667. Pada tahap ke 2, yakni antara rantai budi daya kakao dengan industri pengolahan biji kakao kering/agroindustri yang menghasilkan produk pasta coklat, lemak coklat dan bubuk coklat memiliki biaya transaksi sebesar Rp35.545.833. Pada tahap berikutnya rantai budi daya kakao, agroindustri tahap 1 dengan agroindustri hilir kakao/agroindustri tahap 2 yang menghasilkan produk permen coklat, bubuk coklat mix, menghasilkan biaya transaksiRp27.605.000. Pada tahap terakhir antara rantai budi daya kakao - agroindustri tahap 1 sampai agroindustri tahap 2 dengan agroindustri kreatif/kuliner berbahan baku coklat memiliki biaya transaksi sebesar Rp13.416.667. tingginya biaya transaksi pada tahapan agroindustri karena adanya biaya lobby dan penyiapan lahan bagi pabrik mini kakao untuk mendapatkan 
insentif teknologi dari pemerintah. Hal ini menunjukkan bahwa perlu adanya intervensi pemerintah pada tahap 2 , integrasi dari tahap budi daya ke tahap pengolahan biji kakao fermentasi. Biaya yang ditanggung oleh kelompok cukup tinggi termasuk biaya investasi dan biaya lobby. Pemerintah dapat mengurangi biaya ini menjadi lebih efisien dengan memberikan insentif teknologi untuk mengurangi biaya investasi dan lebih pro aktif melakukan sosialisasi program ke kelompok tani untuk mengurangi biaya lobby.

Integrasi vertikal menunjukkan korelasi positif dengan kelayakan usaha groindustri kakao. Jika usaha ini dikerjakan secara terpisah-pisah maka usaha yang layak adalah pada rantai tahap awal dan tahap akhir (kuliner coklat). Nilai BC rasio tahap 1, tahap 2 tahap 3 dan tahap 4 dari rantai agroindustri kakao adalah 1,$21 ; 0,84 ; 0,97$; dan 1,31 . Jikai usaha ini dintegrasikan antara tahap 1 dan tahap 2, nilai BC rasio masih belum layak $(0,96)$. Integrasi vertikal tahap 1 , tahap 2 dan tahap 3 memberikan nilai $\mathrm{BC}$ rasio 1,12, yang berarti usaha layak secara ekonomis. Hal ini mengindikasikan bahwa bantuan teknologi yang telah diberikan kepada pelaku usaha kakao skala kecil harus terintegrasi dengan suplai bahan baku dan memperhatikan skala usaha yang layak secara ekonomi dan finansial.

\section{Saran}

Untuk meningkatkan daya sing dan nilai tawar petani terhadap komoditas kakao, pemerintah perlu mempertimbangkan kelayakan usaha dan integrasi secara vertikal antara masing-masing rantai nilai agroindustri kakao agar bantuan pemerintah dapat berdaya guna dan berhasil guna. Pemerintah perlu mendorong petani untuk melakukan fermentasi biji kakao. Perlu peran yang sangat kuat dari pemerintah untuk mengintegrasikan antara masing-masing rantai nilai, dan mendorong pengusaha untuk bermitra dengan petani agar petani memperoleh manfaat yang berkeadilan untuk komoditas yan mereka tanam.

Penelitian selanjutnya dapat menganalisis kelayakan integrasi vertikal untuk kondisi biji kakao yang difermentasi dan tidak difermentasi. Perlu juga penelitian lebih lanjut aspek teknologis dan kelembagaan tentang persyaratan yang harus disiapkan oleh kelompok tani agar intergrasi vertikal layak dan berjalan dengan baik.

\section{DAFTAR PUSTAKA}

Ambarawati A, Aragón AO, Bloom E. 2015. Increased incomes for Indonesian cocoa farmers in sustainable markets: NGO-private sector cooperation on Sulawesi Island full case study. Leuven: Rikolto.

Buzzel RD. 1983. Is vertical integration profitable? Harvard Business Review January 1983.

Chen S-FS. 2010. Transaction cost implication of private branding and empirical evidence. Strategic Management Journal 31(4): 371-389.

Coase R. 1937. The nature of firm. Economica, New series. 4(16): 386-405. https://doi.org/10.1111/ j.1468-0335.1937.tb00002.x.

Commonwealth of Australia. 2006. Handbook of Cost-Benefit Analysis January 2006. Australia: Department of Finance and Administration Financial Management Group.

Dann S. 2010. Redefining social marketing with contemporary commercial marketing definitions. Journal of Business Research 63(2):147-153. https://doi.org/10.1016/j.jbusres.2009.02.013.

Davis J, Caskie P, Wallace M. 2013. Promoting structural adjustment in agriculture: the economics of New Entrant Schemes for farmers. Journal of Food Policy 40:90-96. https://doi.org/10.1016/j. foodpol.2013.02.006.

Fischer E, Qaim M. 2012. Linking smallholders to markets: determinants and impacts of farmer collective action in Kenya. Journal of World Development. 40(6):1255-1268. https://doi. org/10.1016/j.worlddev.2011.11.018.

Hanley N, Barbier EB, Barbier E. 2009. Pricing Nature: Cost-benefit Analysis and Environmental Policy. Cheltenham: Edward Elgar Publishing.

Haynes J, Cubbage F, Mercer E, Sills E. 2012. The search for value and meaning in the cocoa supply chain in Costa Rica. Journal of Sustainability. 4(7):1466-1487.https://doi.org/10.3390/ su4071466.

Iqbal M, Anugrah IS. 2009. Rancang bangun sinergi kebijakan agropolitan dan pengembangan ekonomi lokal menunjang percepatan pembangunan wilayah.JurnalAnalisis Kebijakan Pertanian 7(2):169-188.

Normansyah S. 2013. Sustainable Supply Chain Management: A case study on cocoa industry in Indonesia. Journal Bulletin of Indonesian Economic Studies 49(1):114-115. 
North DC. 1990. Institutions, Institutional Change and Economic Performance. Cambridge: Cambridge University Press.

[Pusdatin]. 2016. Outlook Komoditas Kakao 2016: Pusat Data dan Sistem Informasi Pertanian. Jakarta: Sekretariat Jenderal Kementerian Pertanian.

Putri AS, Sutopo W, Prihawantara S, Matheos RCD. 2015. Value chain improvement for cocoa industry in Indonesia by input-output analysis. Di dalam: Proceedings of the International MultiConference of Engineers and Computer Scientists 2015 Vol II. Hongkong, March 18 - 20, 2015. Hong Kong: IMECS.

Rifin A. 2015. The impact of export tax policy on cocoa farmers and supply chain. The International Trade Journal 29(1):39-62. https://doi.org/10.1 080/08853908.2014.941048.

Ruttan VW, Hayami Y. 1984. Toward a theory of induced institutional innovation. The Journal of Development Studies 20(4):203-223. https://doi. org/10.1080/00220388408421914.

Sinaga BM, Susilowati SH. 2007. Dampak kebijakan ekonomi di sektor agroindustri terhadap distribusi pendapatan sektoral, tenaga kerja dan rumah tangga di Indonesia. Journal of SocioEconomic of Agriculture and Agribusiness (SOCA) 7(2):1-19.

Sriwana IK, Arkeman Y, Syah D, Marimin. 2014. Analisa dan mitigasi risiko rantai pasok agroindustri kakao yang berkelanjutan. Jurnal Industri Hasil Perkebunan 9(2):69-79.

Trebbin A. 2014. Linking small farmers to modern retail through producer organizations - Experiences with producer companies in India. Journal of Food Policy 45:35-44. https://doi.org/10.1016/j. foodpol.2013.12.007.

Tresliyana A, Fariyanti A, Rifin A. 2015. Daya saing kakao Indonesia di pasar internasional. Jurnal Manajemen \& Agribisnis 12(2):150-162. http:// dx.doi.org/10.17358/jma.12.2.150 .

Williamson OE. 1985. The Economic Institutions of Capitalism. New York: Oxford University Press.

Williamson OE. 2010. Transaction Cost Economics: The natural progression. Journal of Retailing 86(3):215-226.https://doi.org/10.1016/j. jretai.2010.07.005.

Yustika AE. 2007. Corporate governance of sugar mills in East Java: atransaction cost economics perspective. Jurnal Manajemen dan Kewirausahaan (Journal of Management and Entrepreneurship) 9(1): 1-17.

Zulfiandri, Maarif MS, Hermawan A, Hardjomidjojo H. 2017. The transformation process of cocoa farmers groups to agro-industry groups in Indonesia: a soft system methodology approach. International Journal of Sciences: Basic and Applied Research 31(1):1-30. 